\title{
Women in Public Space: Socio-cultural and Political Undertones in Sudraka's Mrcchakatika
}

\author{
Jai Singh \\ Assistant Professor of English, \\ Department of Indian and World Literatures, \\ English and Foreign Languages University, Hyderabad, India.
}

\author{
https://doi.org/10.3126/litstud.v34i01.39523
}

\begin{abstract}
Any work of art directly or indirectly is a product of contemporary society. Sudraka's Mrcchakatikais an amalgam of the extremely complex socio-cultural circumstances, economic relations of their society, and cross-cultural influences of Greek presence in India. This confluence of various forces is visible in Sudraka's delineation of women characters especially Ganikas. Construction of woman persona i.e. Vasantasena is as per the theories of art and popular notions prevalent in those days however she does not conform to the tradition wholly, in many respects she challenges the accepted norm of the women prevalent in those days.
\end{abstract}

Keywords: Socio-cultural, ApsarāCult, Daņdin, Courtesan, Arthasastra

Apparently works of art are products of imagination but they are also complex amalgam of socio-cultural circumstances, economic relations of their society, and cross-cultural influences. Sudraka's Mrcchakatikaalso encompasses complexities of the contemporary society which are reflected by the women characters especially Ganikas. According to Berry, the representation of public women in Sanskrit Drama is a resultant of Greek influence which entered Indian subcontinent, by 326 B.C. when, "Alexander the Great had crossed the Hindu Kush, occupied Kabul, gone over the Indus River, taken the city of Taxila, .... During these years of occupation, the Greeks contacted Chandragupta Maurya, shaper of the great Indian Mauryan Age and the hero of a sixth-century A.D. historical play, The Minister's Signet Ring" (Berry 404). However, according to Arthur Berriedale Keith, "For Indian drama generally and the Mrcchakatika in particular the case for Greek influence differs markedly" (Keith 57).

Many of the scholars have studied this influence on Sanskrit Drama. Berrystates that "The first extended study of Greek influence on Indian drama appears in a late nineteenth-century study of Albrecht Weber" (Berry405) to 
the effect that "the necessary impetus to creation [of drama] may have been given by the contact of Greece with India through the representation of Greek plays at the courts of the kings in Bactria, the Panjab, and Gujarat" (Gupta650654). In this regard Keith proclaims, "It is impossible to deny that the Sanskrit drama came into being during the period when Greek influence was present in India [....] There is nothing chronologically difficult about assuming the influence of Greek drama on the drama in India" (Keith60-61). Moreover, Keith points out, Alexander and his followers were fond of theatrical spectacles, and they invariably brought companies of performers to the provinces they conquered.

According to Singh, "the intermingling of Perso-Greek and Indian cultures, first in the North-Western India, and, later at the court of Mauryas, we become aware of the beginning of the institution of prostitutes and its association with the royal household, as stated earlier" (Singh187) .In PersoGreek Culture this institution of public women got established instantly because "the institution is connected with the libido it took no time in gaining popularity among those who could afford a mistress of exquisite beauty and charming manners. This is not surprising. The Greek hetaera culture was much developed and it was the place of a hetaera which used to serve the purpose of a venue for the meetings of intellectuals" (Light339). However, according to Torn, in Indian subcontinent "it started later when the Indo-Bactrians established their hold over Bactria and North-Western India. And as soon as beautiful Greek slave girls, having the background of Greek hetaera culture, started coming to India, the courtesan culture began to develop" (Torn373374). At the same time,Singh foregrounds that "the impact of Greek culture was realised in India mainly after the establishment of Indo-Baetrian Greek rule which was followed by the Śakas, Parthians and Kusān as. The cherished ideals of Sakas and Kusāņas were Syrian Greek and Chinese courts" (Singh 188).

Mrcchakatikais apparently very simple and straightforward in the delineation of its plot and story however this simple delineation is based on the foundation of complex socio-cultural, and economic relations of the contemporary society in its depiction of the protagonist Vasantasena and other female characters. Vasantsena belongs to the special category of women characters found in ancient Indian literatures known as Ganikas, many thinkers believe that Ganikas were an important part of public life for instance D. D. Kosambi while analysing the Indus civilization tries to associate the great bath of Mohenjodaro with the "apsarā Cult" (Kosambi 68). Thus according to him people used to enjoy the beautiful girls who were taken as the representatives of the mother Goddess (Kosambi: 68). In the light of his statement, we can 
assume that it was practised with great pomp and show in the garb of a religious ritual. The courtesans enjoyed a lot of respect and were treated as the symbol of status, and embodiment of social niceties. Their status appears to be similar to those of the hetaerae of Greece.

Margaret Berry establishes the relationship between the locale of the play, Mrcchakatikca i.e. Ujjain, institution of public women, and the eroticism in the following words:

The world of prostitution in the Ujjain is more highly structured and institutionalized. It corresponds to that joy in nature, that revelry in sheer physicality, . . . along with their exuberant literature, in perhaps the second millenium B.C. The opulence of Indian erotics shows brilliantly in the Mrcchakatikca. (Berry410)

In Mrcchakatikca the love world of Ujjain is foregrounded through the description of Vasantasena's palace. Tracing her journey to her lover in the middle of a monsoon reflects Indian sensuousness. Similarly, Jesse Ross Knutson foregrounds the complex relationship of the text with the society by establishing relationship between political power, poverty, erotic love and patriarchal society while saying,

"Sūdraka'sLittle Clay Cart (Mrcchakatika), combines uncharted of political intrigue and antagonism, the mutual constitution of poverty and political power - even approximating a kind of social realism - with the other more standard rasas of erotic love and heroism, fear, and pity" (Knutson: 92).

Knutson's view is strengthened when Cārudatta sees poverty as a fate worse than death: "Far better death than sorrows sure and slow;/ Some passing suffering from death may flow,/ But poverty brings never-ending woe"(7). This is how poverty is seen from the male point of view; however, women arepersuaded to look at poverty differently. She is trained to see, true virtue (guna) is coextensive with poverty in the world of the Mrcchakatikain particular and Indian context in general.On the other hand, for men it is equal to castration as the power to extend charity is equal to sexual potency as Goodwin, in his introduction to Basham's English version of the Mrcchakatika, points out that Cārudatta develops the idea that for the hero poverty is a form of impotence: "we emerge with the portrait of a man who sees generosity as a sort of sexual potency and a claim on the general admiration of society" (Goodwin9).His poverty has oblique references to sexual potency in the first act where a powerful erotic feeling for Vasantasenā, was abruptly restricted by poverty: 
Chārudatta. What! this is Vasantasenā? [Aside.]

My love for whom-my fortune spent-

My wretched self in twain has rent.

Like coward's anger, inward bent. (23)

This quotation throws light on the powerful position of man in the society which is consolidated with the help of money. In the absence of money and hence powerful position, man loses manhood that is whyChārudatta who is now without money and hence manhood finds it difficultto approach her, because, by virtue of her wealth, she is his social superior. He is literally impotent. The protagonist is unheroic, and in the play's typically inverted manner, the heroine is made to pursue him as a lover. Cārudatta remarks in a different context in the third act:

Chārudatta. What! my wife takes pity on me? Alas, now am I poorindeed!

When fate so robs him of his all,

That on her pity he must call,

The man to woman's state doth fall,

The woman is the man.(55)

The play foregrounds that the gender roles are determined by economic relationships in the society that is why Chārudatta feels that wealth is essential to preserve the gender roles. If a woman possesses wealth she assumes the role of master and hence belongs to masculine gender on the other hand if a man loses wealth he is forced to take the role of servant and hence forced to display feminine qualities. In the absence of money and hence power Cārudatta gets a feeling of beingcastrated and self-loathing. Due to this particular feeling in the ninth act when he is tried for the murder of Vasantasenā - he has been wrongfully accused, as she is not dead, only unconscious, after being attacked by the villain Sakāra - he says virtually nothing in his defence.

He collaborates with the authority of his oppressors and silently allows himself to be sentenced to death which is like an attempted suicide. His castration was an insufficient punishment, which prefigured his embrace of death. However, women and people from marginal sections who are castrated subjects are trained to look at poverty as a type of wealth. This virtue of Cārudatta that he himself dislikes, is appreciated by other disempowered characters - by Âryaka, even by the Cāñdālas, who are about to execute him becomes the basis for a conception of nobility based only on pure virtue, untainted by wealth.

In Mrcchakatika the gaņikā is called guñānuraktā (one who loves the virtue alone). From Daņdin as recorded inDasakumï̈racaritam it is apparent 
that a courtesan who is categorically mentioned as a gun a-šulkā (one who cares only for the qualities of a person in relation to her fee) in contrast to an ordinary prostitute known as dhana-šulkā (one who takes money as her fee) (Dasakumiïracaritam: 173-174).

The text delineates not only the economic status but also the educational status. The author also tells us about the education which a courtesan was supposed to have as a must (Dasakumï̈racaritam 132-133), as well as artistic excellence of Ganikas as they were "given instructions in the various branches of the fine arts along with other subjects like literature, etc. (Dasakumiüracaritam132 -133). Regarding the emergence of the class of Ganika or courtezan or courtesan and their socio-cultural, political, and economic status, Singh states, "In view of the prosperity and popularity of Vaišâli which was accrued due to the charm of $\bar{A}$ mbapālī, the traders of Magadha, it is said, had projected with the consent of the King a nymph" (184). As per the Vinaya Pitaka 1966 edition "Salavat is the name of first Ganika" who was very conscious of her business because of the tough competition between herself and Ambapāli(28). Singh further says:

people's attempt to make a place attractive and comfortable by providing scope for sexual pleasure for adventurist -traders who used to remain away from their homes for years to come. And, thus they certainly liked the places where public women were in plenty. The traders' role is apparent from the fact that it were they who introduced Bimbisāra to Āmbapālī, and later, when she gave birth to a child, again it was a trader who carried the child to his father Bimbisāra. (184)

Vedic texts belonging to the sixth century B. C. do not speak about even ordinary prostitutes. However as per Arthasastra"by the time of Mauryas the class of ordinary prostitutes had acquired a social sanction and it had gained some place within the royal seraglio also" (XXVIL).

However, Arthasastra does not give any description which can be matched with the account of a sophisticated courtesan like Vasantasenã. Thus, according to Y B Singh "it appears that the beginning of the social concept accepting courtesan as a symbol of social niceties and grace had started taking shape only after the development of India's contact with Greece in general and establishment of Indo-Bactrian Greek rule in India in particular" (185). One possibility is that around this time expensive social institution like that of the hetaerae were established on important routes. The texts like Kämasütra and Mrcchakatika were composed after the fusion of Indian and Indo-Greek 
cultural motifs due to the coming of Indo-Bactrian Greeks therefore the characters Ganika or courtezan or courtesan appear thin these texts that too with peculiar social status they occupied in that society.

The most important achievement of the Mrcchakatika is that it renders fully developed form of a hetaerae type courtesan culture through the character of Vasantasenā which is generally ascribed to the pre-Kālidāsa days (Majumdar: 264).From this period onward the class is mentioned in the writings of almost all the important dramatists, story writers, among others. Moreover, the post-Mrcchakatika period is marked with the texts which deal the class of ganikā in detail.

According to Pendse, "Mrcchakatika is very different from other classical dramas in its characters, context and style. The author of this drama has depicted a variety of characters and incidents, which have a bearing on social life of that time" (238). On the one hand, it connects to the Greek hetaerae culture; on the other hand, it reflects the influence of Käma-Sütra which is also a product of confluence of two cultures. Vasantasenã the leading female is the perfect embodiment of Vätsyäyana idea of a heroine or Nayika who is always beautiful and sweet in conversation, less by wealth, whose love or achieve union by pure affection, loves artistic achievements. However, the dramatist hints at the social attitude towards a beautiful woman artist's body as a public body which can be consumed by anybody and everybody and she cannot say no as the author puts it:

Courtier. [Aside.] What! is it possible that the idiot does not understand when she says "You weary me"? [Aloud.] Vasantasenā, your words have no place in the dwelling of a courtezan, Which, as you know, is friend to every youth; Remember, you are common as the flower That grows beside the road; in bitter truth, Your body has its price; your beauty's dower Is his, who pays the market's current rate:

Then serve the man you love, and him you hate. And again:

The wisest Brahman and the meanest fool

Bathe in the selfsame pool;

Beneath the peacock, flowering plants bend low,

No less beneath the crow;

The Brahman, warrior, merchant, sail along

With all the vulgar throng.

You are the pool, the flowering plant, the boat;

And on your beauty every man may dote. (13) 
This extract from the play hints at the contemporary attitude towards female body especially if she is a public woman. In this society the body of woman who has public life becomes a public property and she loses right on her body. On the other hand, if she is confined to the domestic sphere her body is private property and she has no right on her body. The text of Mrcchakatika has good number of instances where the males have negative ideas about woman for instance Maitreya while in conversation with Charudatta says,

And so, Brahman though I am, I hereby fall on my face before you and beg you not to have anything more to do with this courtezan. That sort of society does any amount of damage. A courtezan is like a pebble in your shoe. It hurts before you get rid of it. And one thing more, my friend. A courtezan, an elephant, a scribe, a mendicant friar, a swindler, and an asswhere these dwells, not even rogues are born. (77)

Charudatta the protagonist also harbours the same kind of ideas about women and takes Vasantasena for a prostitute who on the other hand has true love for him. Charudatta gives a much-generalized statement about women when he says:

If wealth is thine, the maid is thine,

For maids are won by gold;

[aside. And not by virtue cold. Aloud.]

But wealth is now no longer mine,

And her I may not hold.(77)

This kind of statements appeal to the popular culture. Contrary to the popular male perception of woman's personality Vasantasena is a true lover, a serious thinker and practical in her dealings as evident from her statement about her love towards Charudatta:

Vasantasena. And yet, sir, why scold one who is so ignorant of woman's nature? For you must remember:

The clouds may rain, may thunder ne'er so bold,

May flash the lightning from the sky above;

That woman little reeks of heat or cold,

Who journeys to her love.(82)

Here Sudraka in the portrayal of Vasantasena defies Vätsyäyana's conception of a Ganika who emphasizes the artificial nature of the love of a Ganikä for the sake of riches, and advises her to practise this artificial behaviour just like natural, so that the confidence of men can be won. The entire chapter of Kãntãnuvrtti is described to give an idea of a false demonstration of feelings and emotions, which a Ganikä has to practise to win 
the confidence of her lover. Vätsyäyana also describes vividly the different types of behaviours, which are practised by Ganikãs to abandon the man devoid of wealth under the title Niskãsanakramãh. The heroine Vasantasena contrary to Vätsyäyana's idea has true love for Charudatta and sacrifices her wealth for love's shake.

She is even ready to sacrifice her life for love when Sakãra's Vita tries to convince Vasantasenã, on behalf of Sakãra whom he serves to follow the laws of normal prostitution and please his rich companion. However, when Vasantasenã refuses it flatly, he realises that the Gem must go with the Gem', and her love of Cãrudatta is justified by him. He appreciates her attitude of opposition, and also helps her protect herself. He is such a conscientious man that he ultimately feels disgusted with his vicious master and leaves his service.

Male idea of woman's nature completely fails here and further Shudraka constructs different perspectives on the storm and the sentiment of love (shringar rasa), along gender lines, Vasantasena's description of the storm, provides glimpses into some of her complex feelings, all of them variations on "love in separation." She visualizes nature in its personified form. She displays ample knowledge of scriptures when she pleads with Indra -in order to co-opt him to her side - by reminding him how he lied to be able to make love to Ahalya, a mythical woman married to another man:

For Ahalyā's sweet sake thou once didst lie;

Thou knowest lover's pain.

As thou didst suffer then, now suffer I;

O cruel, cease thy rain.(86)

In the storm scene, we see various facets of Vasantasena's personality. The thundering, profusely raining cloud (a male) frightens her but also excites her. As a young woman, she experiences both erotic longing and slight fear as reflected in her image of a shameless cloud who, while frightening her with his thunder, touches her all over with his hands in the form of showers. The dramatist purposely uses the plural form of "hand" to denote intensity, when in Sanskrit the dual form was available.

Vasantasena. O shameless, shameless sky

To thunder thus, while I

To him I love draw nigh.

Why do thy thunders frighten me and pain?

Why am I seized upon by hands of rain?

...

Thunder and rain and lighten hundredfold

Forth from thy sky above; 
The woman canst thou not delay nor hold

Who journeys to her love.

Let thunders roar, for men were cruel ever;

But oh, thou maiden lightning! didst thou never

Know pains that maidens know.(85-86)

Sudraka takes a break from the tradition and infuses different hues and shades related to love and eroticism as reflected in Vasantasena's display of annoyance and feigned anger towards the naughty cloud, which, in a very subtle manner hints at her sexual excitement and unlike the women characters in existing drama makes her a woman conscious of her physical needs. With the depiction of these features in the character of Vasantasena,Sudraka highlights his inclination towards the modern day feminism. In another scene in Act I when Vasantasena is troubled by Sansthanaka (the king's brother-in-law) and she is on the verge of being violated by him, shedescribes the storm calling up the images of lonely women separated from their lovers or snatched violently from their husbands. Obviously, she feels empathic toward the plight of such women.

Not just the female body which is political and economic body, the male body also forms a part of politics. For instance, Chärudatta's character is depicted as per Vatsyäyana's description and a lot of power is associated with him. Vãtsyãyana mentions some important qualities for a Nãyaka, which can be easily seen in the case of Chärudatta. He was a correct Nägaraka, as described by Vãtsyãyana. He was well-versed in tirts, young, highly virtuous, self -sacrificing in his attitude, and came from a very noble family. In this respect he is very near to the tragic hero of Aristotle. Picnicking in the gardens of the city was very popular in the days of Vãtsyãyana. His description of Udyãnayãtrã agrees in all particulars with facts given in Mrcchakatilca, with the only difference that Chärudatta goes in a bullock-cart instead of on horseback. A very subtle instruction has been passed by Vãtsyãyana that Ganikä should avoid a personality related to kings and who is wicked. Šakára is such a character, related to the king and is wicked and Vasantasenã entirely disliked him.

Mrcchakatikamseems to be a reflecting mirror of its contemporary society. Deviation from prescribed rules of morality, police atrocities, gambling, thievery, prostitution, litigation, biased verdicts and many other social distortions can be seen in this distinctive dramatic work of Sudraka. The high character of Charudatta really enchants the reader's mind. He is the noblest of human beings who helps himself in his helplessness. He has been entrapped in the murder case of Vasantasena. The hangmen make fun and utter satirical remarks about him. The judges also accuse him. Construction of 
woman persona i.e. Vasantasena is as per the theories of art and popular notions prevalent in those days however she does not conform to the tradition wholly, in many respects she challenges the accepted norm of the women prevalent in the society when the play was written.

\section{Works Cited}

Berry, Margaret. "Plautus, Terence and the Mrcchakatika."Comparative Literature Studies 19.1 (1982): 403-415.

Dandin.Dasakumï̈racaritam. Trans. T Bhattacharya and K. Sarma. 4. Varanasi: Chaukhamba AmabrabharatiPrakashan, 1978.

Dasgupta, Surendra Nath. A History of Sanskrit Literature: The Classical Period. Vol. 1. Calcutta: The University of Calcutta Press, 1962.

Goodwin, Robert E. "Introduction." Šūdraka. The Little Clay Cart. SUNY series in Hindu Literature. Ed.

Arvind Sharma. Trans. A. L. Basham. Albany: State University of New York Press, 1994.

Keith, Arthur Berriedale. The Sanskrit Drama in its Origin, Development, Theory and Practices. London: Oxford University Press, 1924.

Kosambi, Damodar Dharmananda.The Culture and Civilization of Ancient India in Historical Outline.Routledge, London, 1965.

Knutson, Jesse Ross. "Money Morality, and Masculinity: Staging the Politics of Poverty in Sanskrit Theatre."Philosophy East and West 66.1 (2016): 90-103.

Light, H. Sexual Life in Ancient Greece. London: George Routledge \& Sons Ltd., 1932.

Majumdar, Ramesh Chandra\&Achut DattatrayaPusalker. Eds. The Age of Imperial Unity. Bhagatiya Vidya Bhawan, Bombay, 1965.

Pendse, G. S. "The Influence of Kāma-Sūtra on Mr cchakaț ika."Annals of the Bhandarkar Oriental Research Institute. Vol. 54, No. 1.4. 1973. 238247.

Ryder, Arthur William. The Little Clay Cart (Mr cchakat ika). Attributed to King Sudraka. Cambridge: Harvard University Press. 1905.

Singh, Y. B. "Roots of the Gan ikā-Culture of Early India."Annals of the BhandarkarOriental Research Institute. Vol. 74, No. 1.4 (1993). 181190.

Torn, W. W. The Greeks in Bactria and India. Delhi: MunshiramManoharlal, 1980.

Vinaya Pitaka Vol. VITI. N. Wagle, Society at the time of Buddha. Popular Prakashan, Bombay, 1966. 172-173. xx 